\title{
PURIFICATION OF CELLULOSE-BINDING PROTEINS 1 AND 2 FROM CELL LYSATE OF FIBROBACTER SUCCINOGENES $\mathrm{S} 85$
}

\author{
MAKOTO MITSUMORI* AND HAJIME MINATO \\ National Institute of Animal Health, Tsukuba 305, Japan
}

(Received December 7, 1992)

\begin{abstract}
Attempts were made to separate and purify cellulose-binding proteins (CBPs) from the lysate of cells of Fibrobacter succinogenes S85, utilizing their affinity to cellulose. After Avicel cellulose was incubated in the culture treated with Tween 20 at $37^{\circ} \mathrm{C}$, cellulose was washed with buffer containing Softes 12 as a detergent to remove the cell debris and proteins incapable of adhering to cellulose. Proteins strongly adhering to cellulose after washing were eluted with buffer containing 10\% cellobiose. The eluent contained mainly two major proteins and one minor protein. When the eluent, concentrated by ultrafiltration, was dialyzed against distilled water, small particles of aggregate appeared in it. The dialyzed eluent was separated into soluble and insoluble fractions by high speed centrifugation. Proteins present in both the soluble fraction and the solution of the insoluble fraction dissolved in buffer containing Softes 12 were purified by treatment with a saturated solution of ammonium sulfate. Protein purified from the soluble fraction was designated as CBP1 and protein from the insoluble fraction as CBP2. The molecular weight of CBP1 and CBP2 was approximately 120 and 225 kilodaltons (kDa), respectively. The culture containing a cell lysate of the bacterium exhibited such enzyme activities as $\beta$-glucosidase, cellobiosidase and CMCase, whereas both CBP1 and CBP2 did not show these enzyme activities. Both CBP1 and CBP2 displayed adhering ability to cellulose powder, but not to starch granules.
\end{abstract}

Many morphological types of microorganisms are associated with plant materials in the rumen microbial ecosystem (1-3). It has been generally recognized that the washing-out rate of the microorganisms adhering to plant materials is slower than that of the microorganisms living freely in the liquid digesta in the rumen (4).

* Address reprint requests to: Dr. Makoto Mitsumori, National Institute of Animal Health, 3-1-1 Kannondai, Tsukuba 305, Japan. 
These findings suggest that adhesion enables the microorganisms to utilize more effectively the slowly digestible cellulosic materials. Therefore, to improve the efficiency of digestion by ruminants of low quality forages in particular, it is necessary to develop a technique whereby the number of microorganisms possessing both the ability of adhering to plant materials and a high digestive ability would increase in the rumen. Basically, studies on the adhesion of microorganisms to plant materials as well as studies on the hydrolytic enzymes involved in the digestion should be promoted.

Fibrobacter succinogenes is one of the predominant cellulolytic bacteria in the rumen. Therefore, studies on the purification and characterization of the hydrolytic enzymes responsible for the degradation of cellulose and hemicellulose have been carried out extensively $(5,8-10)$. Moreover, it has been demonstrated that adhesion of the bacterium to cellulose is essential for cellulose digestion (7). On the other hand, although studies on the physicochemical and physiological factors affecting the adhesion of bacteria to cellulose have been carried out $(11,12)$, there are very few studies on the substances involved in the adhesion of cells of the bacterium to cellulose (14).

We have demonstrated the presence of cellulose-binding proteins (CBPs) in the lysate of cells of this bacterium (13). In this report, the separation and purification of CBPs from the lysate of cells of the bacterium and some of their characteristics are described.

\section{MATERIALS AND METHODS}

Organism and growth condition. Fibrobacter succinogenes S85 (ATCC 19169) was anaerobically grown at $37^{\circ} \mathrm{C}$ in the same medium (SD medium) described in our previous report (13).

Preparation of a mixture of cellulose-binding proteins (CBPS). F. succinogenes S85 was grown at $37^{\circ} \mathrm{C}$ for $24 \mathrm{~h}$ in a $10-l$ bottle containing $5 l$ of the SD medium. After $10 \mathrm{~g}$ of Avicel microcrystalline cellulose PH-101 (Asahi Chemical Industry, Ltd., Tokyo, Japan) was added to the culture treated with $1 \%(\mathrm{v} / \mathrm{v})$ Tween 20 and the mixture was agitated at $37^{\circ} \mathrm{C}$ for $1 \mathrm{~h}$, the mixture was allowed to stand at room temperature for $30 \mathrm{~min}$ to settle cellulose. Then, the cellulose pellet was transferred to a 300-ml centrifuge tube. The cellulose pellet was suspended in $50 \mathrm{ml}$ of Buffer A [ $1 \%(\mathrm{v} / \mathrm{v})$ Softes 12 (Wako Pure Chemical Industries, Ltd., Osaka, Japan)-1 mM $\mathrm{CaCl}_{2}-1 \mathrm{mM} \mathrm{MgCl}_{2}-50 \mathrm{~mm}$ sodium phosphate buffer ( $\mathrm{pH}$ 6.5)] and the cellulose suspension was distributed into 2 tubes. The tubes were incubated at $37^{\circ} \mathrm{C}$ for 10 min, then vigorously agitated, and incubated at $37^{\circ} \mathrm{C}$ for a further $10 \mathrm{~min}$. And the cellulose was washed 7 times with $25 \mathrm{ml}$ of Buffer A, to remove cell debris and proteins incapable of adhering to it. After that, CBPs were eluted with Buffer B [Buffer A supplemented with 10\% (w/v) cellobiose] from cellulose. The two tubes were incubated at $37^{\circ} \mathrm{C}$ for $20 \mathrm{~min}$ in a water bath with agitating every $10 \mathrm{~min}$. After centrifuging the tubes at $2,500 \mathrm{rpm}$ for $3 \mathrm{~min}$ at room temperature, the 
supernatant fluids were collected. Finally, a total of $100 \mathrm{ml}$ of the eluents was used as CBPs.

Separation of crude CBP1 and CBP2 from CBPs. The eluent containing CBPs was concentrated approximately 2.5 fold by ultrafiltration in a MINITAN-S system (Millipore Corp., Bedford, Massachusetts, U.S.A.) equipped with a 10,000-molecular-weight cutoff membrane at $4^{\circ} \mathrm{C}$. When the concentrated fluid was dialyzed 6 times against distilled water at $4^{\circ} \mathrm{C}$, small particles of aggregate appeared. The mixture was separated into both soluble and insoluble fractions by high speed centrifugation. The soluble fraction was used as the fraction of a crude CBP1; while, the insoluble fraction was suspended in $1 \mathrm{ml}$ of distilled water and the suspension was used as the fraction of a crude CBP2.

Purification of CBP1 and CBP2. To the fraction of crude CBP1 (55 ml), an equal volume of a saturated solution of ammonium sulfate was added with gently agitating in an ice bath. The mixture was centrifuged at 2,000 rpm for $5 \mathrm{~min}$ at room temperature and separated into two layers. The upper layer, which shows white color and is mainly composed of Softes 12, was a thin solidified layer; while, the bottom layer was soluble. The soluble portion was collected carefully to avoid contamination with the upper layer. The soluble portion was desalted and concentrated by ultrafiltration in a MINITAN-S system equipped with a 10,000-molecular-weight cutoff membrane at $4^{\circ} \mathrm{C}$. After the soluble portion was concentrated to $9.7 \mathrm{ml}$ finally, ten-fold concentrated Buffer A was added to the desalted soluble portion to give a final concentration of $1 \times$ Buffer $A$. The protein solution dissolved in Buffer A was used as purified CBP1.

The microtube (Assist Trading Co., Ltd., Tokyo, Japan) containing the crude CBP2 $(0.9 \mathrm{ml})$ was centrifuged at $15,000 \mathrm{rpm}$ for $10 \mathrm{~min}$ at $4{ }^{\circ} \mathrm{C}$. The sediment was washed twice with $0.9 \mathrm{ml}$ of distilled water by centrifugation. The washed sediment was suspended in $0.9 \mathrm{ml}$ of Buffer $\mathrm{A}$ and left at $4{ }^{\circ} \mathrm{C}$ for overnight in order to dissolve it. The solution was mixed with an equal volume of a saturated solution of ammonium sulfate on ice. The mixture was centrifuged at 5,000 rpm for $5 \mathrm{~min}$ at $4^{\circ} \mathrm{C}$ and separated into soluble and insoluble fractions. The insoluble fraction was dissolved in $0.9 \mathrm{ml}$ of Buffer A without Softes 12. This treatment with a saturated solution of ammonium sulfate was repeated three times. The protein solution dissolved in Buffer A was used as purified CBP2.

Binding of purified CBP1 and CBP2 to cellulose powder and starch granules. For examining the adhering ability of purified CBP1 and CBP2 to cellulose and starch, the solutions of CBP1 and CBP2 were diluted with Buffer A to give a final concentration of $20 \mu \mathrm{g}$ protein $/ \mathrm{ml}$ and $10 \mu \mathrm{g}$ protein $/ \mathrm{ml}$, respectively. Five milligrams of Avicel cellulose or corn starch granules (Wako) were added to a $1.5-\mathrm{ml}$ microtube containing $50 \mu 1$ of CBP1 solution or CBP2 solution. The tubes were incubated at $37^{\circ} \mathrm{C}$ for $20 \mathrm{~min}$ in a water bath. After that, cellulose or starch was removed by low speed centrifugation. And, the supernatant fluids were collected and analyzed by sodium dodecyl sulfate-polyacrylamide gel electrophoresis (SDSPAGE). 
To examine the relationship between the quantity of cellulose added and the amount of CBP1 and CBP2 adhered to it, the suspension $(25 \mu \mathrm{l})$ containing varied quantities of cellulose were added to the solution $(25 \mu \mathrm{l})$ of CBP1 (20 $\mu \mathrm{g}$ protein $/ \mathrm{ml})$ or CBP2 $(10 \mu \mathrm{g}$ protein $/ \mathrm{ml})$. The treatment of the mixtures was performed according to the same procedures as described above. After SDS-PAGE of the samples, the protein bands in the gels was quantified by using a densitometer (Shimadzu Corp., Kyoto, Japan; Dual-Wavelength TLC Scanner Model CS-930).

Enzyme assays. $\beta$-Glucosidase and cellobiosidase activities were assayed by using $p$-nitrophenyl- $\beta$-D-glucopyranoside (Sigma Chemical Co., St. Louis, M. O., U.S.A.) and $p$-nitrophenyl- $\beta$-D-cellobioside (Sigma), respectively, as the substrates. To each well of 96-well microtiter plate (Sumitomo Bakelite Co., Ltd., Tokyo, Japan), $0.025 \mathrm{ml}$ each of 2-fold concentrated Buffer A, sample and aqueous solution containing $1 \mathrm{~mm}$ substrate were added. The plates were incubated at $37^{\circ} \mathrm{C}$ for $1 \mathrm{~h}$ in a wet chamber. The reaction was stopped by adding $0.05 \mathrm{ml}$ of $1 \mathrm{mM} \mathrm{Na} \mathrm{CO}_{3}$. $p$-Nitrophenol release was calculated from the absorbance at $405 \mathrm{~nm}$ by using EIA reader (Bio-Rad Laboratories, Richmond, California, U.S.A.; Model 2550).

Carboxymethylcellulase (CMCase) activity was determined by the amount of glucose liberated from carboxymethylcellulose (CMC) (Wako). The reaction mixture in a $1.5-\mathrm{ml}$ microtube contained $0.05 \mathrm{ml}$ each of Buffer A containing $1 \%$ $(\mathrm{w} / \mathrm{v}) \mathrm{CMC}$ and sample. After $1 \mathrm{~h}$ of incubation at $37^{\circ} \mathrm{C}$, the reaction was stopped by heating the tubes in boiling water for $5 \mathrm{~min}$. The reducing sugars liberated in each tube were determined by a mutarotase-glucose oxidase method (Wako; Glucose C II-Test Wako kit).

Protein assays. Protein was determined by the method of Lowry modified by Wang and Smith (18). Protein concentrations were determined by using $0.1 \mathrm{ml}$ of sample, diluted to an appropriate concentration with Buffer A when it was necessary. Bovine serum albumin (Bio-Rad), dissolved in Buffer A, was used as a standard.

Sodium dodecyl sulfate-polyacrylamide gel electrophoresis (SDS-PAGE). The SDS-PAGE was performed according to the same method as described in our previous report (13).

\section{RESULTS AND DISCUSSION}

\section{Preparation of CBPs from cell lysate of $F$. succinogenes $S 85$}

Attempts were made to isolate CBPs from the cell lysate of $F$. succinogenes S85, which were prepared by treatment of the whole culture with Tween 20 . The turbidity of the whole culture of the bacterium decreased and the solution eventually became clear, after treatment with Tween 20 . The whole culture treated with Tween 20 contained many types of proteins (Fig. 1; Lane a). In order to adhere CBPs to cellulose, Avicel cellulose was incubated with the whole culture containing cell lysate. When the mixture was spun by low speed centrifugation, the mixture was separated into supernatant and cellulose pellet fractions, and the cellulose pellet 


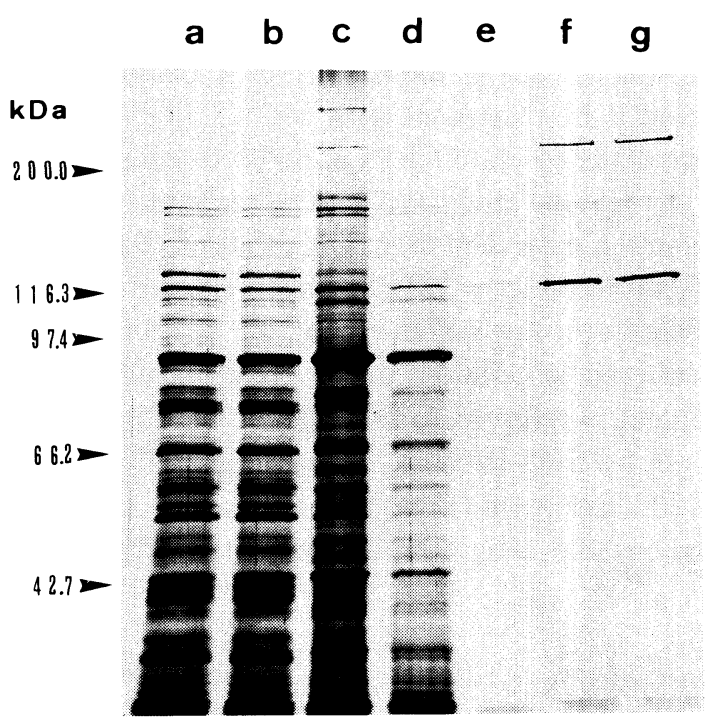

Fig. 1

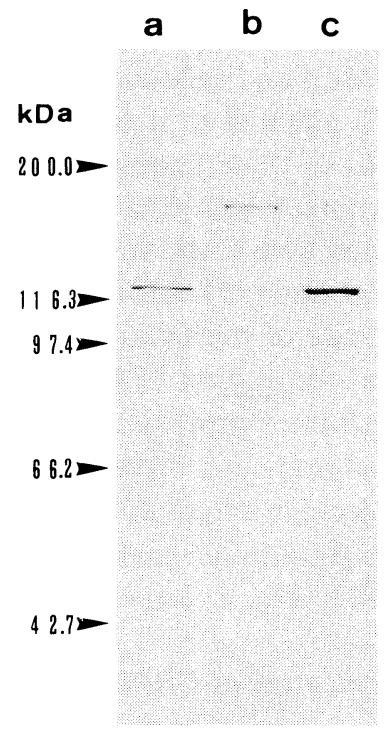

Fig. 2

Fig. 1. SDS-PAGE profiles of whole culture of $F$. succinogenes $\mathrm{S} 85$ after the treatment with Tween 20, and of CBPs eluted with 10\% cellobiose from Avicel cellulose adhered with CBPs.

Lane a, whole culture treated with Tween 20; Lane b, supernatant obtained after whole culture was incubated with cellulose; Lane c, supernatant obtained by washing of cellulose with Buffer A; Lane d, supernatant obtained by second washing of cellulose with Buffer A; Lane e, supernatant obtained by final washing of cellulose with Buffer A; Lane f, first eluent eluted with $10 \%$ cellobiose from cellulose; Lane g, second eluent eluted with $10 \%$ cellobiose from cellulose. Arrows at left indicate locations of standard proteins with molecular weights given in thousands.

Fig. 2. SDS-PAGE analysis of crude CBP1 and purified CBP1.

Lane a, crude CBP1 obtained after dialysis against distilled water; Lane b, insoluble fraction by treatment of crude CBP1 with a saturated solution of ammonium sulfate; Lane c, purified CBP1. Arrows at left indicate locations of standard proteins with molecular weights given in thousands.

was covered with a layer of muddy substances. To remove the muddy substances containing cell debris and proteins incapable of adhering to cellulose, the cellulose pellet was washed with buffer containing various kinds of detergents. For this purpose, the only effective detergent was Softes 12 (data not shown). The muddy substances were removed from the cellulose pellet by the repetition of washing with Buffer A. The solutions of both a first and second wash contained various and abundant proteins (Fig. 1; Lanes $\mathrm{c}$ and d). On the other hand, the solution of a seventh wash did not contain a detectable amount of proteins by SDS-PAGE (Fig. 1; Lane e). Such enzyme activities as $\beta$-glucosidase, cellobiosidase and CMCase were detected in the whole culture treated with Tween 20 , and the solutions of a first and second wash; whereas, the solutions of third to seventh wash did not exibit any of these enzyme activities. 
It has been demonstrated that methylcellulose (MC), carboxymethylcellulose (CMC) and cellobiose inhibited adhesion of cells of the bacterium to cellulose and cells adhered to it were detached from it by treatment with $\mathrm{MC}(7,11)$. On the basis of these findings, attempts were made to elute CBPs adhered to cellulose by treatment with CMC or cellobiose in previous study (13). The amount of CBPs eluted with CMC from cellulose was much more abundant than that of CBPs with cellobiose (13). However, it was difficult to remove CMC from eluents through the process of purification of CBPs. Therefore, the buffer containing cellobiose was used for elution of CBPs strongly adhered to cellulose in the present study. The mixture of proteins present in the eluent is referred to as CBPs. The CBPs were separated into three bands in the gel by SDS-PAGE. The major protein with molecular weight of approximately 120 kilodaltons $(\mathrm{kDa})$ was designated as CBP1, and the another major protein with molecular weight of approximately $225 \mathrm{kDa}$ as CBP2 (Fig. 1; Lanes $f$ and g).

\section{Purification of CBP1 and CBP2 from CBPs}

Attempts were made to purify CBP1 and CBP2 from CBPs. A summary of the purifications of CBP1 and CBP2 is given in Table 1.

CBP1 was purified from the soluble fraction containing crude CBP1 according to the procedures described in Materials AND Methods. The purified CBP1 fraction did not contain any contaminating proteins (Fig. 2). The amount of CBP1 recovered after the purification procedures was $560 \mu \mathrm{g}$. The molecular weight of purified CBP1 was approximately $120 \mathrm{kDa}$. The CBP1 did not exhibit such enzyme activities as $\beta$-glucosidase, cellobiosidase and CMCase.

CBP2 was purified from the crude CBP2 fraction, containing several kinds of contaminating proteins (Fig. 3), according to the procedures described in MATERIALS AND METHODS. The amount of CBP2 recovered after the purification procedures was $25.0 \mu \mathrm{g}$. The molecular weight of purified CBP2 was approximately

Table 1. Purification of CBP1 and CBP2.

\begin{tabular}{|c|c|c|c|c|}
\hline \multirow[t]{2}{*}{ Purification step } & \multirow{2}{*}{$\begin{array}{l}\text { Total protein } \\
(\mathrm{mg})\end{array}$} & \multicolumn{3}{|c|}{$\begin{array}{c}\text { Enzyme activity } \\
(\mathrm{nmol} / \mathrm{min} / \mathrm{mg} \text { protein })\end{array}$} \\
\hline & & $\beta$-Glucosidase & Cellobiosidase & CMCase \\
\hline Whole culture treated with Tween 20 & 19,500 & 0.7 & 15.9 & 6.4 \\
\hline \multicolumn{5}{|l|}{$\begin{array}{l}\text { The solution obtained by washing } \\
\text { cellulose pellet adhered } \\
\text { with CBPs with Buffer A }\end{array}$} \\
\hline 1st wash & 58.5 & 0 & 713.0 & 652.1 \\
\hline 2nd wash & 22.4 & 0 & $1,629.0$ & 774.2 \\
\hline 7 th wash & 0.8 & 0 & 0 & 0 \\
\hline \multicolumn{5}{|l|}{ Crude CBPs eluted with $10 \%$} \\
\hline cellobiose from cellulose & 9.8 & 0 & 0 & 221.0 \\
\hline Purified CBP1 & 0.56 & 0 & 0 & 0 \\
\hline Purified CBP2 & 0.025 & 0 & 0 & 0 \\
\hline
\end{tabular}




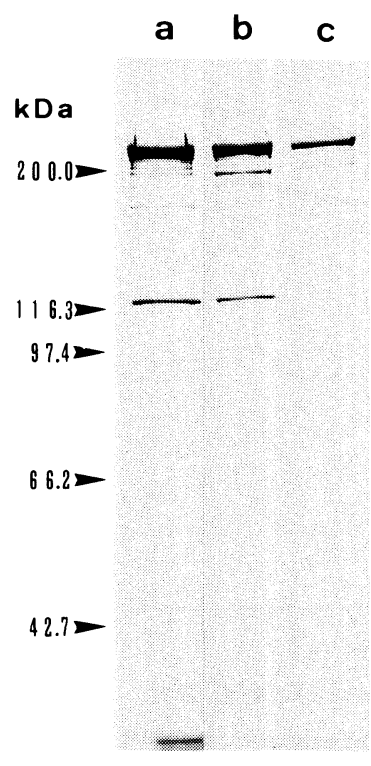

Fig. 3

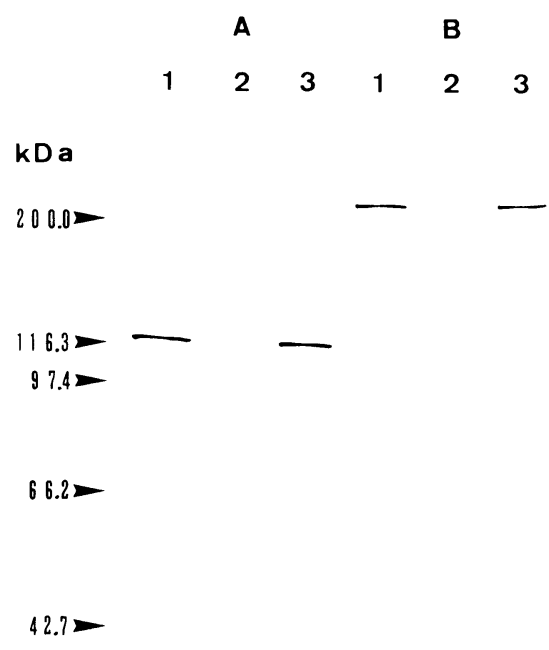

Fig. 4

Fig. 3. SDS-PAGE analysis of crude CBP2 and purified CBP2.

Lane a, crude CBP2 obtained after dialysis against distilled water and suspended in distilled water; Lane b, crude CBP2 dissolved in Buffer A; Lane c, purified CBP2. Arrows at left indicate locations of standard proteins with molecular weights given in thousands.

Fig. 4. Adhesion of CBP1 and CBP2 to cellulose powder and starch granules.

(A) Lane $1,0.1 \mu \mathrm{g}$ of purified CBP1; Lane 2, supernatant obtained after the solution of CBP1 was incubated with cellulose; Lane 3, supernatant obtained after the solution of CBP1 was incubated with starch granules. (B) Lane $1,0.05 \mu \mathrm{g}$ of purified CBP2; Lane 2, supernatant obtained after the solution of CBP2 was incubated with cellulose; Lane 3, supernatant obtained after the solution of CBP2 was incubated with starch granules. Arrows at left indicate locations of standard proteins with molecular weights given in thousands.

$225 \mathrm{kDa}$. The CBP2 did not exhibit such enzyme activities as $\beta$-glucosidase, cellobiosidase and CMCase.

\section{Binding of purified $C B P 1$ and $C B P 2$ to cellulose and starch}

An attempt was made to examine the adhering ability of purified CBP1 and CBP2 to Avicel cellulose and starch granules. After the solution of CBP1 or CBP2 dissolved in Buffer A was treated with cellulose powder, most of CBP1 and CBP2 were removed from the solution (Fig. 4). On the other hand, the amount of CBP1 or CBP2 present in the solution did not change before and after the treatment with starch granules (Fig. 4). These results show that CBP1 and CBP2 are capable of adhering to cellulose, but incapable of adhering to starch. 


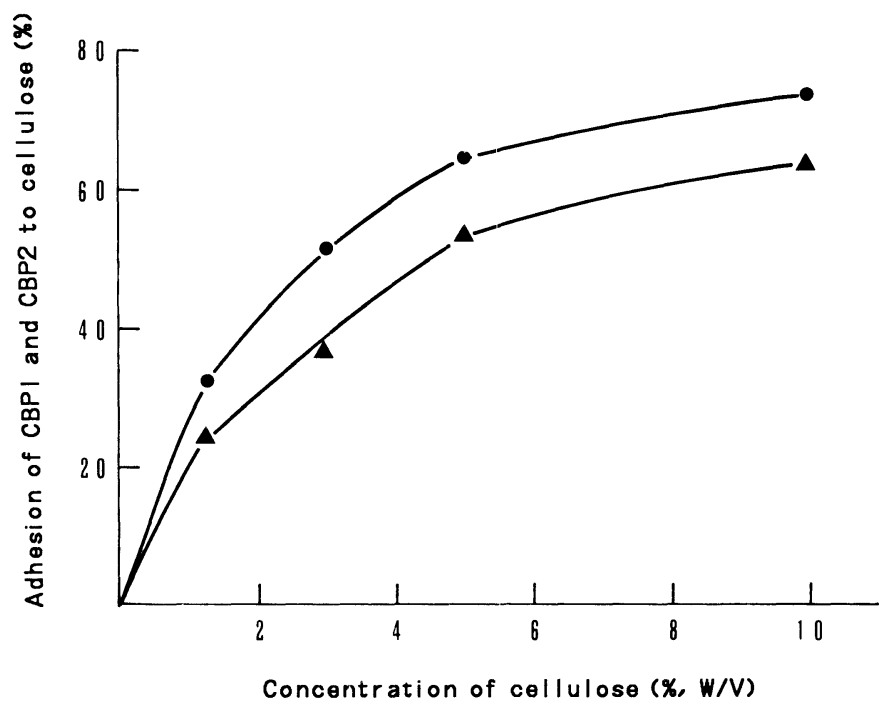

Fig. 5. Effect of the quantity of cellulose on the amount of CBP1 or CBP2 adhered to it.

Adhesion of CBP 1 and CBP 2 to cellulose was calculated from the following equation: adhesion of CBP1 and CBP2 to cellulose $(\%)=100-(A / B \times 100)$, where $A$ indicates $A_{600}$ of CBP1 or CBP2 treated with cellulose in the SDS-PAGE gel, and $B$ indicates $A_{600}$ of CBP1 or CBP2 not treated with cellulose in the SDS-PAGE gel. adhesion of CBP1; $\mathbf{\Delta}$, adhesion of CBP2.

The relationship between the quantity of cellulose added and the amount of CBP1 or CBP2 adhered to it was examined. The amount of both CBP1 and CBP2 adhered to cellulose increased with the quantity of cellulose added (Fig. 5).

As for rumen bacteria isolated from the rumen, although it was found that there are two types of cellulases having both catalytic and cellulose-binding sites and having only catalytic site $(6,10,15)$, CBPs with no apparent enzymatic activity have not been demonstrated until now. On the other hand, as for Clostridium cellulovorans and Clostridium thermocellum of nonruminal bacteria, it has been demonstrated that the cellulase complex from these bacteria comprises the subunit having adhering ability to cellulose without detectable enzymatic activity $(16,17)$. Moreover, Shoseyov and Doi (16) on their findings have proposed a working hypothesis that the adhesion of the $170 \mathrm{kDa}$ subunit having adhering ability to cellulose converts the crystalline cellulose to a form that is capable of being hydrolyzed in a cooperative fashion by the associated catalytic subunits (endoglucanases).

Further work is necessary to analyze the role of these CBP1 and CBP2 in the degradation of cellulose by $F$. succinogenes $\mathbf{S} 85$ and to clarify the mechanism of adhesion of cells of the bacterium to cellulose at molecular and cellular levels. 


\section{REFERENCES}

1) Akin, D. E., Chemical and biological structure in plants as related to microbial degradation of forage cell walls. In Control of Digestion and Metabolism in Ruminants, ed. by Milligan, L. P., Grovum, W. L., and Dobson, A., Prentice-Hall, Englewood, N.J. (1986), p. 139-157.

2) Cheng, K. J. and Costerton, J. W., Adherent rumen bacteria: Their role in the digestion of plant material, urea and epithelial cells. In Digestive Physiology and Metabolism in Ruminants, ed. by Ruckebush, K. and Thivend, P., MTP Press, Lancaster (1980), p. 117-132.

3) Czerkawski, J. W. and Cheng, K. J., Compartmentation in the rumen. In The Rumen Microbial Ecosystem, ed. by Hobson, P. N., Elsevier Applied Science, London and New York (1988), p. 361-385.

4) Falchney, G. J., Measurement in sheep of the quantity and composition of rumen digesta and the fractional outflow rates of digesta constituents. Aust. J. Agric. Res., 31, 1129-1137 (1980).

5) Forsberg, C. W., Beveridge, T. J., and Hellstrom, A., Cellulase and xylanase from Bacteroides succinogenes and its importance in the rumen environment. Appl. Environ. Microbiol., 42, 886-896 (1981).

6) Gilkes, N. R., Henrissat, B., Kilburn, D. G., Miller, R. C., and Warren, R. A. J., Domains in microbial $\beta$-1,4-glycanases: Sequence conservation, function, and enzyme families. Microbiol. Rev., 55, 303-315 (1991).

7) Kudo, H., Cheng, K.-J., and Costerton, J. W., Electron microscopic study of the methylcellulosemediated detachment of cellulolytic rumen bacteria from cellulose fibers. Can. J. Microbiol., 33, 267-272 (1987).

8) Martin, S. A. and Akin, D. E., Effect of phenolic monomers on the growth and $\beta$-glucosidase activity of Bacteroides ruminicola and on the carboxymethylcellulase, $\beta$-glucosidase, and xylanase activities of Bacteroides succinogenes. Appl. Environ. Microbiol., 54, 3019-3022 (1988).

9) McGavin, M. and Forsberg, C. W., Isolation and characterization of endoglucanases 1 and 2 from Bacteroides succinogenes S85. J. Bacteriol., 170, 2914-2922 (1988).

10) McGavin, M. and Forsberg, C. W., Catalytic and substrate-binding domains of endoglucanase 2 from Bacteroides succinogenes. J. Bacteriol., 171, 3310-3315 (1989).

11) Minato, H. and Suto, T., Technique for fractionation of bacteria in rumen microbial ecosystem. II. Attachment of bacteria isolated from bovine rumen to cellulose powder in vitro and elution of bacteria attached therefrom. J. Gen. Appl. Microbiol., 24, 1-16 (1978).

12) Minato, H. and Suto, T., Technique for fractionation of bacteria in rumen microbial ecosystem. IV. Attachment of rumen bacteria to cellulose powder and elution of bacteria attached to it. $J$. Gen. Appl. Microbiol., 27, 21-31 (1981).

13) Mitsumori, M. and Minato, H., Presence of several cellulose-binding proteins in cell lysate of Fibrobacter succinogenes S85. J. Gen. Appl. Microbiol., 39, 273-283 (1993).

14) Montogomery, L. and Fu, Y.-K., Detection of cellulose-binding proteins in electrophoresis gels by filter paper affinity blotting. Anal. Biochem., 174, 204-208 (1988).

15) Ohmiya, K., Kajino, A., Kato, A., and Shimizu, S., Structure of a Ruminococcus albus endo-1,4$\beta$-glucanase gene. J. Bacteriol., 171, 6771-6775 (1989).

16) Shoseyov, O. and Doi, R. H., Essential 170-kDa subunit for degradation of crystalline cellulose by Clostridium cellulovorans cellulase. Proc. Natl. Acad. Sci. USA, 87, 2192-2195 (1990).

17) Tokatlidis, K., Salamitou, S., Beguin, P., Dhurjati, P., and Aubert, J. P., Interaction of the duplicated segment carried by Clostridium thermocellum cellulases with cellulosome components. FEBS Lett., 291, 185-188 (1991).

18) Wang, C. S. and Smith, R. L., Lowry determination of protein in the presence of Triton X-100. Anal. Biochem., 63, 414-417 (1975). 